\title{
Adsorpsi Air dari Campuran Uap Etanol-Air dengan Zeolit Sintetis 4A pada Packed Bed Dalam Rangka Produksi Fuel Grade Ethanol
}

\author{
Handrian*, Wahyudi Budi Sediawan, dan Aswati Mindaryani \\ Departemen Teknik Kimia, Fakultas Teknik, Universitas Gadjah Mada \\ Jl Grafika No. 2 Kampus UGM, Yogyakarta, 55283 \\ *Alamat korespondensi: handrian261@gmail.com
}

(Submisi: 11 November 2017; Revisi: 4 Desember 2017; Penerimaan: 7 Desember 2017 )

\begin{abstract}
A B S T RACT
Ethanol can be used as fuel if it has a purity of 99.5\%. To produce this high purity grade, separation by distillation is not appropriate since it will stop at its azeotrop point, i.e. at 95.6\%. Molecular sieve adsorption is one of methods to obtain ethanol with level above the azeotropic point. Adsorbent that serves as molecular sieve, for example, is synthetic zeolite 4A. The adsorbent has a pore diameter of $3.9 \dot{A}$. Water and ethanol have a molecular diameter of $2.75 \dot{A}$ and $4.4 \dot{A}$, respectively. Hence, the adsorbent is selective against the ethanol-water mixture. The purpose of this research is to obtain ethanol with higher purity than its azeotropic point concentration. Furthermore, the influence of flow rate $\left(v_{z}\right)$ and temperature $(T)$ on design parameters i.e. the number of mass transfer coefficient $\left(k_{c}\right)$, effective diffusivity $\left(D e_{r}\right)$, and Henry constants $\left(H^{\prime}\right)$ were studied. The experiment was conducted by weighing zeolite $4 A$ as much as 100 grams, then stacked to a certain height in the packed bed column. The heating regulator was switched on and set to constant temperature of $80,85,90,95$, and $100^{\circ} \mathrm{C}$. Ethanol of $95.61 \%$ with $250 \mathrm{ml}$ volume was put into a threeneck flask, then heated until evaporation. During the proccess, the cooling system was turned on. The adjustment of evaporation rate was carried out by adjusting the faucet opening and the degree of voltage in the heating mantle. The magnitude of the vapor flow rate was set to 2, 4, and $6 \mathrm{~L} /$ minute. The product was collected and samples were taken every minute to analyze the ethanol content. The experiment showed that the highest yield of ethanol with $99.40 \%$ was achieved. The steam flow rate of $2 \mathrm{~L} /$ minute (lpm) and the temperature of $80^{\circ} \mathrm{C}$ was the optimum combination in this research. In this case, the water vapor adsorbed on the $4 A$ zeolite grain was up to $7.93 \mathrm{~g}$. The evaluation exhibited that the value of De $e_{r}$ was $1.59 \times 10^{-3} \mathrm{~cm}^{2} /$ minute. The relation of $k_{c}$ as the function of Reynolds number and $H^{\prime}$ as the function of temperature are as follows:
\end{abstract}

$k_{c}=7.95 \times 10^{-3}\left(\frac{\rho v_{z} D}{\mu}\right)^{0,164}$ and $H^{\prime}=4.47 \times 10^{-3} \cdot e^{\left(\frac{2565.26}{T}\right)}$

Keywords : adsorption, molecular sieve, packed bed, zeolite $4 A$ 


\section{A B S T R A K}

Etanol dapat digunakan sebagai bahan bakar jika memiliki kemurnian 99,5\%, sedangkan distilasi etanol akan terhenti pada titik azeotropnya, yaitu pada 95,6\%. Adsorpsi molecular sieve adalah salah satu metode untuk memperoleh etanol dengan kadar di atas titik azeotrop. Adsorben yang dapat berfungsi sebagai molecular sieve salah satunya adalah zeolit sintetis 4A. Adsorben ini memiliki diameter pori sebesar 3,9 Á, lalu air dan etanol masing-masing memiliki diameter molekul 2,75 Á dan $4,4 \AA$ Á. Maka dari itu adsorbent bersifat selektif terhadap campuran etanol-air. Penelitian ini bertujuan untuk memperoleh etanol diatas titik azeotropnya serta mempelajari hubungan pengaruh laju alir $\left(v_{z}\right)$ dan suhu $(T)$ terhadap perubahan harga koefisien transfer massa $\left(k_{c}\right)$, difusivitas radial $\left(D e_{r}\right)$ dan konstanta Henry $\left(H^{\prime}\right)$ yang bisa digunakan sebagai parameter dalam perancangan alat adsorpsi pada skala komersial. Percobaan ini dilakukan dengan cara menimbang zeolit 4A sebanyak 100 gram, lalu disusun dan diukur tingginya pada kolom adsorben. Regulator pemanas dinyalakan dan diatur suhunya sampai konstan pada $80,85,90,95$, dan $100^{\circ} \mathrm{C}$. Etanol $95,61 \%$ dengan volume $250 \mathrm{ml}$ dimasukkan ke dalam labu leher tiga, lalu dipanaskan sampai menguap. Pendingin balik dinyalakan dan diatur besarnya laju uap yang terbentuk dengan mengatur bukaan kran dan derajat voltase pada heating mantle. Besarnya laju aliran uap diatur pada 2, 4, dan 6 L/menit (lpm). Produk ditampung dan diambil tiap menit sebagai sampel untuk dianalisis kadar etanolnya. Proses adsorpsi ini memberikan hasil tertinggi berupa etanol dengan kadar hingga 99,40\%. Laju alir uap $2 \mathrm{~L} /$ menit dan suhu $80^{\circ} \mathrm{C}$ adalah kombinasi yang optimal dalam penelitian ini karena banyak uap air yang teradsorpsi pada butir zeolit 4A yaitu 7,93 gram. Perhitungan secara numeris memberikan hasil bahwa nilai $D e_{r}$ pada percobaan ini adalah $1,59 \times 10^{-3} \mathrm{~cm}^{2} /$ menit, serta hubungan $k_{c}$ fungsi Reynolds dan $H^{\prime}$ fungsi suhu berturut-turut adalah sebagai berikut:

$k_{c}=7,95 \times 10^{-3}\left(\frac{\rho v_{z} D}{\mu}\right)^{0,164} \operatorname{dan} H^{\prime}=4,47 \times 10^{-3} \cdot e^{\frac{2565,26}{T}}$

Kata kunci : Adsorpsi, molecular sieve, packed bed, zeolit 4A

\section{Pendahuluan}

Salah satu bahan bakar alternatif pengganti bahan bakar minyak (BBM) adalah etanol atau bioetanol. Etanol yang diproduksi dan dipasarkan maksimum berkadar 95-96\%, karena pada rentang kadar 95-96\% terjadi peristiwa yang disebut azeotrop, yaitu kondisi pada saat campuran etanol-air tidak dapat dipisahkan dengan metode distilasi biasa. Salah satu proses dehidrasi etanol yaitu dengan metode adsorpsi penyaring molekul atau lebih dikenal dengan adsorpsi molecular sieve (MS). Cara kerja metode ini adalah dengan melewatkan campuran etanol-air pada suatu kolom yang berisi bahan penyaring (adsorben). Karena fungsinya sebagai molecular sieve, adsorben harus memiliki ukuran pori selektif. Misalnya diketahui air $\left(\mathrm{H}_{2} \mathrm{O}\right)$ memiliki diameter molekul 2,75 A dan diameter molekul etanol $\left(\mathrm{C}_{2} \mathrm{H}_{5} \mathrm{OH}\right)$ adalah $4,40 \AA$ (Perry,
1997). Maka adsorben harus memiliki diameter pori di antara keduanya.

Adsorben yang umum digunakan dalam dehidrasi air dari etanol adalah zeolit sintetis tipe A dengan diameter pori yang seragam. Zeolit tipe ini terdiri dari zeolit 3A, 4A, dan 5A. Zeolit $3 \mathrm{~A}$ dan $4 \mathrm{~A}$ umumnya dipilih karena memiliki diameter pori yang sesuai untuk proses adsorpsi ini. Dengan mempertimbangkan efek vibrasi terhadap diameter molekul air dan etanol maka dipilih zeolit 4A. Penelitian ini bertujuan untuk 1) memperoleh etanol dengan kadar di atas titik azeotrop dengan metode adsorpsi molecular sieve; 2) mencari nilai koefisien transfer massa $\left(k_{c}\right)$, difusivitas radial $\left(D e_{r}\right)$ dan konstanta Henry $\left(H^{\prime}\right)$ dari data percobaan; 3) mempelajari hubungan pengaruh laju alir $\left(v_{z}\right)$ terhadap $k_{c}$ dan suhu $(T)$ terhadap $H^{\prime}$ yang dapat digunakan 
sebagai parameter dalam perancangan alat adsorpsi pada skala komersial.

Adsorpsi adalah suatu proses yang terjadi ketika suatu fluida (cairan maupun gas) yang menempel pada suatu padatan (adsorben) dan akhirnya membentuk suatu film (lapisan tipis) pada permukaan padatan tersebut. Molekul fluida yang berinteraksi dan melekat pada adsorben disebut adsorbate sedangkan yang tidak melekat disebut adsorptive. Penyerapan atau adsorpsi merupakan proses yang berkesetimbangan, sebab laju peristiwa adsorpsi juga disertai dengan terjadinya peristiwa desorpsi. Ketika laju adsorpsi sama dengan laju desorpsi sering disebut sebagai keadaan setimbang. Mekanisme adsorpsi terbagi menjadi empat tahap (Sediawan, 1997), yaitu:

(1). transfer massa molekul-molekul adsorbate menuju lapisan film yang mengelilingi adsorben,

(2). difusi adsorbate melalui lapisan film (film diffusion),

(3). difusi adsorbate melalui pori-pori dalam adsorben (pore diffusion),

(4). menempelnya adsorbate pada permukaan dinding dalam adsorben.

Zeolit merupakan senyawa kristal alumina silikat. Zeolit dapat dibagi menjadi dua kelompok besar yaitu zeolit alam dan zeolit sintetis. Zeolit alam diperoleh dari endapan di alam, biasanya mengandung bermacam-macam kation $\mathrm{K}^{+}, \mathrm{Na}^{+}$, $\mathrm{Mg}^{2+}$ atau $\mathrm{Ca}^{2+}$. Zeolit sintetis biasanya hanya mengandung kation tunggal yaitu $\mathrm{K}^{+}$atau $\mathrm{Na}^{+}$, sehingga relatif mempunyai ukuran dan diameter pori yang seragam dibandingkan zeolit alam (Mortimer dan Taylor 2002). Maka dari itu zeolit sintetis juga dikenal sebagai zeolite molecular sieve (ZMS).

\section{Metode Penelitian}

\subsection{Bahan Penelitian}

Bahan yang akan digunakan dalam penelitian ini adalah etanol 95,61\% dan zeolit sintetis 4A. Bahan baku berupa etanol azeotrop diperoleh dari CV. Multi Kimia Yogyakarta. Guna memastikan titik azeotropnya dilakukan distilasi sampai mendapat distilat setengah dari umpan. Distilat tersebut diambil sampelnya dan dianalisis dengan gas chromatography (GC). Hasilnya diketahui memiliki kadar etanol 95,61 \% dan air 4,39\%. Zeolit 4A didapat dari Huiying Chemical Products (Quanzhou) yang bermitra dengan CV Genesis Wira Jaya (Surabaya). Data spesifikasi Zeolit 4A yang dapat dilihat pada Tabel 1 .

Tabel 1. Spesifikasi Zeolit 4A

\begin{tabular}{clcl}
\hline No & \multicolumn{1}{c}{ Kriteria } & Hasil & \multicolumn{1}{c}{ Metode Tes } \\
\hline 1 & $\mathrm{SiO}_{2}(\%)$ & 33,7 & \\
2 & $\mathrm{Al}_{2} \mathrm{O}_{3}(\%)$ & 28,6 & $\mathrm{Q} / \mathrm{QZH} 01-95,4.5$ \\
3 & Rasio Si/Al & 1,18 & \\
4 & Bulk density $(\mathrm{g} / \mathrm{ml})$ & 0,774 & $\mathrm{Q} / \mathrm{QZH} 01-94,5.9$ \\
5 & $\begin{array}{l}\text { Kapasitas serap } \\
\text { cairan }(\mathrm{g} / 100 \mathrm{~g})\end{array}$ & 31,04 & Minimixer \\
6 & $\begin{array}{l}\text { Diameter Partikel } \\
\text { rata-rata }(\mathrm{mm})\end{array}$ & 4,5 & Jangka sorong \\
7 & $\begin{array}{l}\text { Surface area }\left(\mathrm{m}^{2} / \mathrm{g}\right) \\
8\end{array}$ & 51,7 & BET surface area \\
& $\begin{array}{l}\text { Porositas partikel } \\
\text { (fraksi v/v) }\end{array}$ & 0,19 & \\
9 & $\begin{array}{l}\text { Diameter pori rerata } \\
\text { (A) }\end{array}$ & 3,9 & $\begin{array}{l}\text { d=4Volum } \\
\text { pori/surface area }\end{array}$ \\
10 & $\begin{array}{l}\text { Particle density } \\
\text { (g/ml) }\end{array}$ & 1,714 & \\
\hline
\end{tabular}

\subsection{Metode Percobaan}

Rangkaian alat dan metode percobaan ditunjukkan pada Gambar 1.

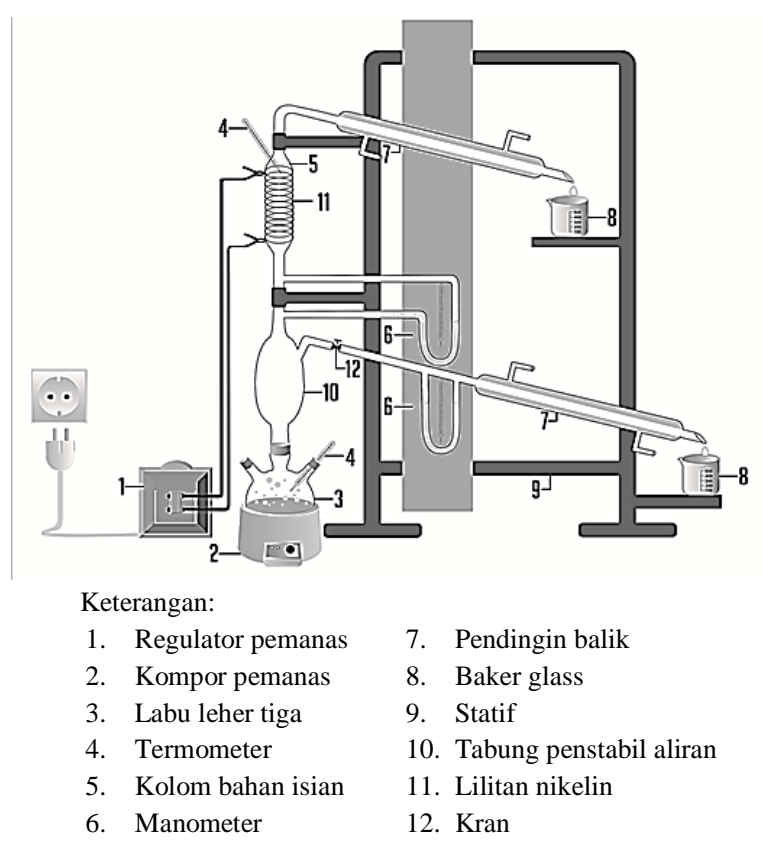

Gambar 1. Rangkaian alat percobaan

Zeolit sintetis 4A dengan berat 100 gram dimasukkan ke dalam kolom kemudian di ukur tinggi tumpukan tersebut. Regulator pemanas 
diyalakan lalu disetel sampai suhu yang diinginkan. Etanol 95,61\% diambil sebanyak 250 $\mathrm{ml}$ dan dimasukkan ke dalam labu leher tiga yang telah dihubungkan dengan pendingin balik. Lalu dipanaskan sampai mendidih. Besarnya laju uap yang terbentuk diatur dengan memutar voltase pada heating mantle dan kran nomor 12 . Besarnya laju aliran uap akan berbanding lurus dengan perbedaan tinggi cairan pada manometer (6) yang sudah diberi tanda. Penentuan $t=0$ adalah saat krusial. Pada $t=0$ adalah waktu kontak pertama antara uap dan tumpukan diposisi $z=0$. Langkah selajutnya mengambil produk tiap menit untuk dianalisis kadarnya. Analisis hasil atau produk dengan GC-MS/GC. Analisis terbagi menjadi dua yaitu analisis kadar mula-mula etanol bahan baku dan kadar etanol produk. Diagram alir penelitian disajikan pada Gambar 2.

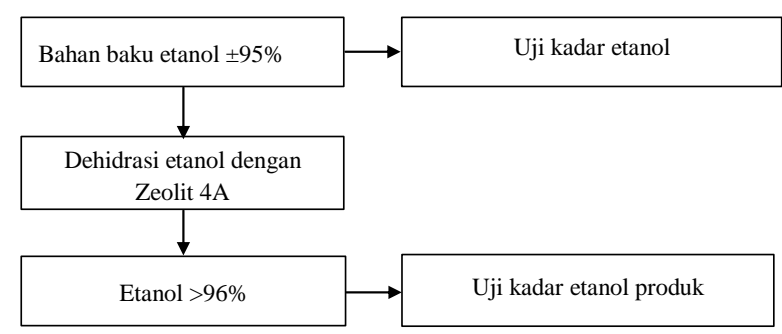

Gambar 2. Diagram alir penelitian

\subsection{Pemodelan Matematis}

Proses adsorpsi terjadi pada permukaan poripori dalam butir adsorben, sehingga transfer massa $\mathrm{H}_{2} \mathrm{O}$ (zat A) ke dalam pori-pori butir adsorben tersebut akan mengalami proses-proses sebagai berikut:

a. Perpindahan massa dari uap ke permukaan butir.

b. Difusi dari permukaan butir ke dalam butir melalui pori.

c. Perpindahan massa dari uap dalam pori ke dinding dalam pori.

d. Adsorpsi pada dinding pori.

Perpindahan massa dari uap zat A dalam pori ke dinding pori (proses c) umumnya berlangsung sangat cepat sehingga tidak mengontrol. Adsorpsi pada dinding pori (proses d) umumnya juga berlangsung relatif sangat cepat, sehingga tidak mengontrol juga. Dengan demikian yang umumnya mengontrol kecepatan proses adsorpsi adalah proses a atau proses $b$ atau keduanya. Jika butir-butir sangat kecil (seperti serbuk) maka difusi dari permukaan ke dalam butir (proses b) berlangsung relatif sangat cepat sehingga tidak mengontrol. Akibatnya yang mengontrol adalah perpindahan massa dari uap ke permukaan butir. Sebaliknya, jika butir-butir berukuran besar, difusi dari permukaan ke dalam butir relatif sangat lambat, sehingga yang mengontrol adalah proses difusinya (Sediawan, 1997).

Perpindahan massa $\mathrm{A}$ arah aksial dalam kolom terjadi karena dibawa arus $\left(=Q . C_{A}\right)$ dan difusi arah aksial $\left(=D e_{z} \frac{\partial^{2} C_{A}}{\partial z^{2}}\right)$. Asumsi aliran dianggap plug flow. Neraca massa pada fixed bed column adsorber dapat ilustrasikan pada Gambar 3.

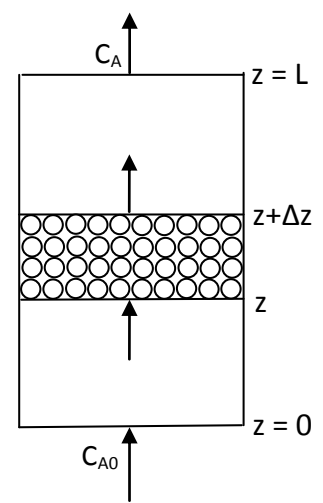

Gambar 3. Fixed bed column adsorber

Neraca massa A pada fase uap dalam elemen volume setebal $\Delta z$ (Persamaan 1$)$ :

Rate of input - Rate of output $=$ Rate of accumulation

$$
\begin{aligned}
& \left(-\left.D e_{z} \cdot S \cdot \frac{\partial C_{A}}{\partial z}\right|_{z}+\left.Q \cdot C_{A}\right|_{z}\right)- \\
& \left(-\left.D e_{z} \cdot S \cdot \frac{\partial C_{A}}{\partial z}\right|_{z+\Delta z}+\left.Q \cdot C_{A}\right|_{z+\Delta z}+\right. \\
& \left.k_{c} \cdot a \cdot\left(\overline{C_{A}}-{\overline{C_{A}}}^{*}\right) \cdot S \cdot \Delta z\right)=S \cdot \Delta z \cdot \varepsilon_{b} \cdot \frac{\partial C_{A}}{\partial t}
\end{aligned}
$$

Dengan mengasumsikan transfer massa karena difusi kecil dibanding transfer massa konveksi, hasil penyelesaian dari Persamaan 1 dapat dituliskan sebagai Persamaan (2).

$$
\frac{\partial \mathrm{C}_{\mathrm{A}}}{\partial \mathrm{z}}+\frac{3 \cdot \mathrm{k}_{\mathrm{c}}}{\mathrm{v}_{\mathrm{z}} \cdot \mathrm{R}} \cdot\left(\mathrm{C}_{\mathrm{A}}-\mathrm{C}_{\mathrm{A}}^{*}\right)=-\frac{\varepsilon_{\mathrm{b}}}{\mathrm{v}_{\mathrm{z}}} \cdot \frac{\partial \mathrm{C}_{\mathrm{A}}}{\partial \mathrm{t}}
$$


Berikutnya disusun persamaan diferensial untuk gradien kadar $\mathrm{H}_{2} \mathrm{O}$ di dalam partikel. Asumsi bentuk partikel adsorben menyerupai bola (Gambar 4).

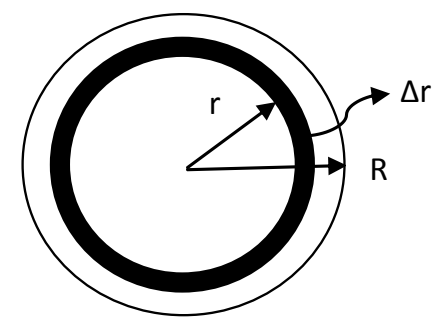

Gambar 4. Butir Adsorben

Tiap butir adsorben memiliki pori, proses adsorpsi diilustrasikan seperti Gambar 5.

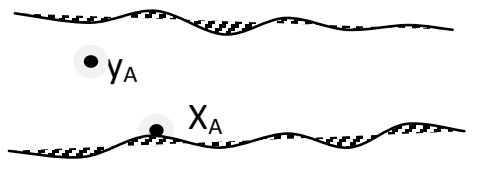

Gambar 5. Pori Butir Adsorben

Misal hubungan kesetimbangan adsorpsi dalam pori adsorben didekati dengan persamaan yang mirip dengan model kesetimbangan Henry (Persamaan 3 dan 4)

$$
\begin{aligned}
& y_{A}=H \cdot X_{A} \\
& C_{A} *=y_{A} \cdot \rho_{S}
\end{aligned}
$$

dengan;

$y_{A}=$ fraksi massa A pada fase gas

$X_{A}=$ fraksi massa A teradsorpsi

Persamaan 3 dan 4 dikorelasikan dengan hukum Henry menjadi Persamaan 5:

$$
\begin{aligned}
& P_{A}=H \cdot X_{A} \\
& y_{A} \cdot P_{t}=H \cdot X_{A} \\
& y_{A}=\left(H / P_{t}\right) \cdot X_{A} \\
& y_{A}=H^{\prime} \cdot X_{A} \\
& C_{A} *=H^{\prime} \cdot X_{A} \cdot \rho_{S}
\end{aligned}
$$

Neraca massa A teradsorpsi dalam adsorben dalam elemen volume setebal $\Delta r$ :

Rate of input - Rate of output $=$ Rate of accumulation

$$
\begin{aligned}
\left(-\left.D e_{r} \cdot 4 \cdot \pi \cdot(r+\Delta r)^{2} \cdot \rho_{s} \cdot \frac{\partial X_{A}}{\partial r}\right|_{r+\Delta r}\right) & \\
& -\left(-\left.D e_{r} \cdot 4 \cdot \pi \cdot r^{2} \cdot \rho_{s} \cdot \frac{\partial X_{A}}{\partial r}\right|_{r}\right)
\end{aligned}
$$

$$
=4 \cdot \pi \cdot r^{2} \cdot \Delta r \cdot \rho_{s} \cdot \frac{\partial}{\partial t}\left(\varepsilon_{p} \cdot y_{A}+\left(1-\varepsilon_{p}\right) \cdot X_{A}\right)
$$

Hasil penyelesaian Persamaan 6 adalah:

$$
\frac{\partial^{2} X_{A}}{\partial r^{2}}+\frac{2}{r} \cdot \frac{\partial X_{A}}{\partial r}=-\left(\frac{\varepsilon_{p} \cdot\left(H^{\prime}+\left(\frac{1-\varepsilon_{p}}{\varepsilon_{p}}\right)\right.}{D e_{r}}\right) \frac{\partial X_{A}}{\partial t}
$$

Persamaan (2) dan (7) digabung kemudian digunakan untuk menganalisis fixed bed adsorber. Metode yang digunakan untuk menghitung secara numeris adalah finite difference approximation cara eksplisit dengan bantuan bahasa program Scilab 5.1.1.

Alur program perhitungan dapat dilihat pada Gambar 6.

\section{Hasil dan Pembahasan}

\subsection{Pengaruh Kadar Air terhadap Laju Alir Uap dan Suhu}

Laju alir uap etanol-air yang melewati packed

\begin{tabular}{|c|c|c|c|c|c|c|}
\hline \multirow[t]{2}{*}{$\begin{array}{c}\text { Waktu, } \\
\text { menit }\end{array}$} & \multicolumn{3}{|c|}{$\begin{array}{c}\text { Data percobaan \% } \\
\text { kadar air pada } \\
\text { berbagai laju alir } \\
\text { uap }\end{array}$} & \multicolumn{3}{|c|}{$\begin{array}{c}\text { Hasil perhitungan \% } \\
\text { kadar air pada } \\
\text { berbagai laju alir } \\
\text { uap }\end{array}$} \\
\hline & $2 \mathrm{lpm}$ & $4 \mathrm{lpm}$ & $6 \mathrm{lpm}$ & $2 \mathrm{lpm}$ & $4 \mathrm{lpm}$ & $6 \mathrm{lpm}$ \\
\hline 0 & 0,00 & 0,0 & 0,00 &, 00 & & 0,00 \\
\hline 1 & & & 0,7 & & & 0,27 \\
\hline 2 & 84 & & 1,02 & 0,07 & 0,6 & 1,32 \\
\hline 3 & 39 & & 2,77 & 4 & & 2,42 \\
\hline 4 & & & 3,81 & 54 & 2,8 & 3,55 \\
\hline 5 & 83 & 4,0 & 4,48 & 2,67 & 3,9 & 4,30 \\
\hline 6 & 82 & & 4,84 & 3,75 & 4,35 & 4,39 \\
\hline 7 & 3,87 & 4,4 & 4,94 & 4,30 & 4,39 & 4,39 \\
\hline 8 & 4,55 & 4,79 & - & 4,39 & 4,39 & 4,39 \\
\hline 9 & 4,50 & - & - & 4,39 & 4,39 & 4,39 \\
\hline
\end{tabular}
bed di variasi dengan kecepatan 2, 4, dan 6 liter/menit (lpm). Suhu dalam bed dijaga konstan pada $80,85,90,95$, dan $100^{\circ} \mathrm{C}$ menggunakan pemanas listrik dengan kumparan nikelin serta diisolasi menggunakan pita asbes. Tiap menit produk dari proses adsorpsi ini diambil dan dianalisis kadar etanol menggunakan GC. Kadar uap air dalam etanol hasil separasi pada suhu 80 ${ }^{\circ} \mathrm{C}$ disajikan pada Tabel 2 dan Gambar 7.

Tabel 2. Kadar air pada berbagai laju alir di suhu tetap $80^{\circ} \mathrm{C}$ 


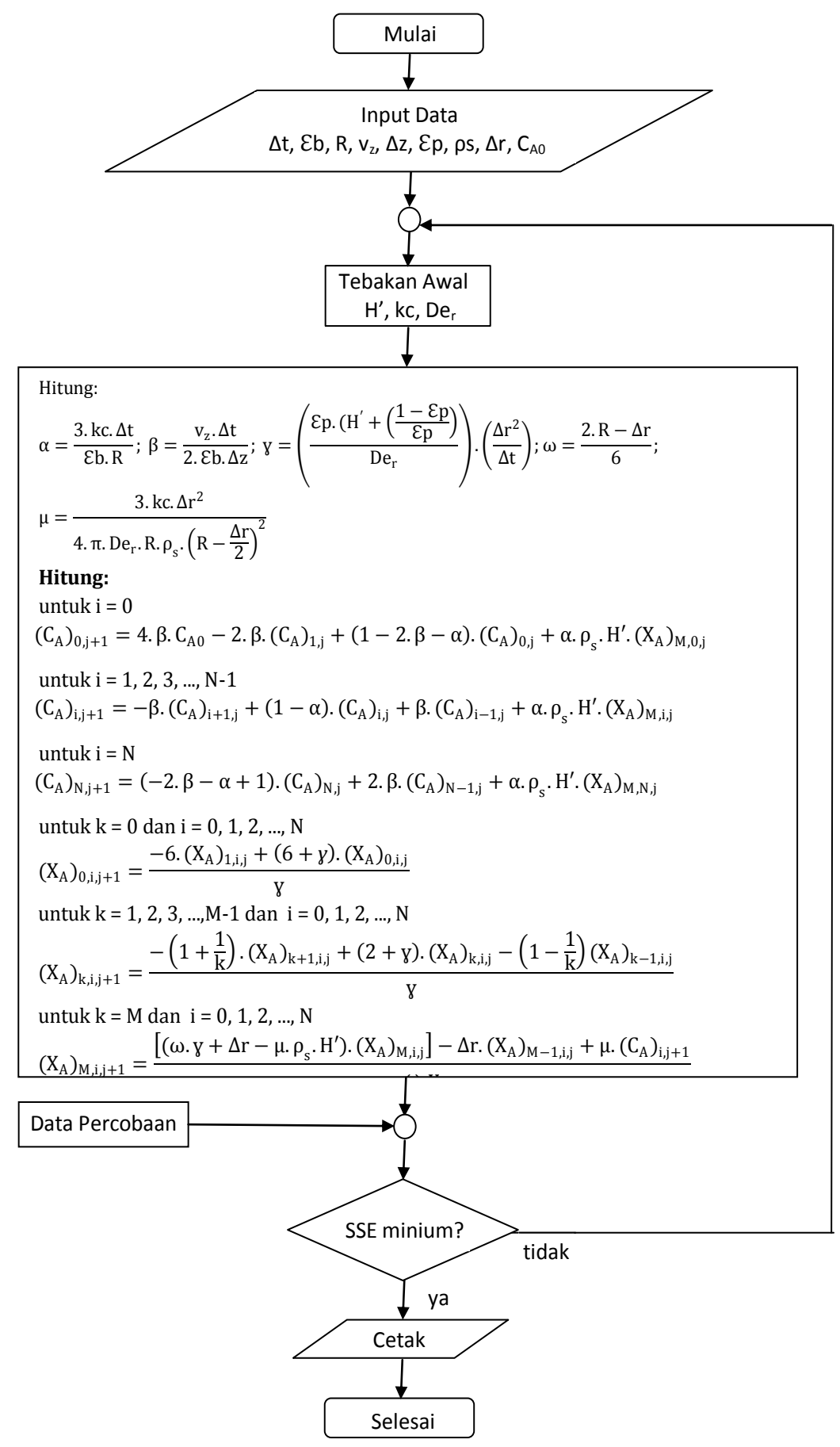

Gambar 6. Diagram alir perhitungan

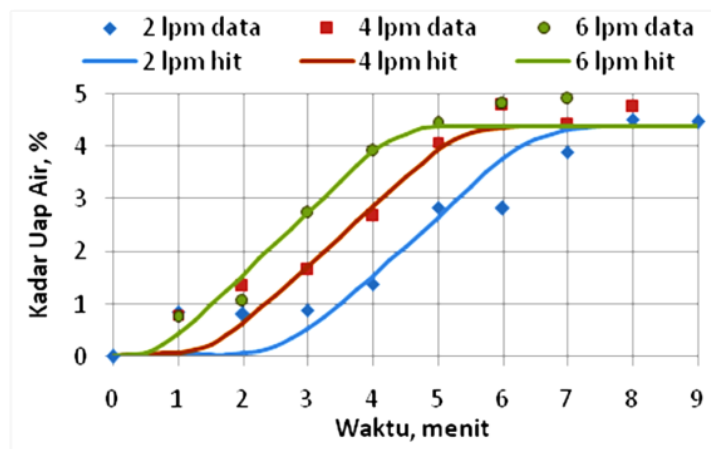

Gambar 7. Kadar air di berbagai laju alir di suhu tetap $80^{\circ} \mathrm{C}$ 
Berdasarkan Tabel 2 dan Gambar 7 tampak bahwa hubungan kadar air pada fase uap terhadap variasi laju alir dan waktu adsorpsi. Secara umum, semakin lama waktu adsorpsi maka semakin besar kadar air. Ini terjadi karena semakin lama semakin sedikit uap air yang tertangkap oleh adsorben. Adsorben memiliki area aktif yang bisa menangkap adsorbate. Area aktif ini berada permukaan dalam dan permukaan luar adsorben. Jika area aktif ini sudah penuh maka proses adsorpsi tidak akan terjadi lagi dan justru bisa terjadi peristiwa desorpsi.

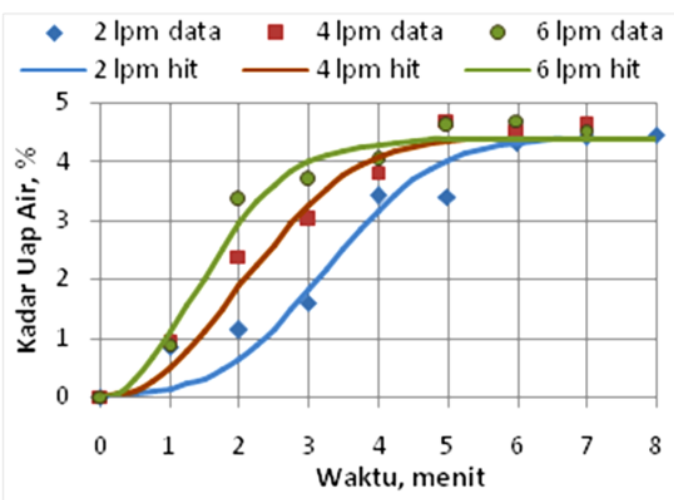

(a). $85^{\circ} \mathrm{C}$

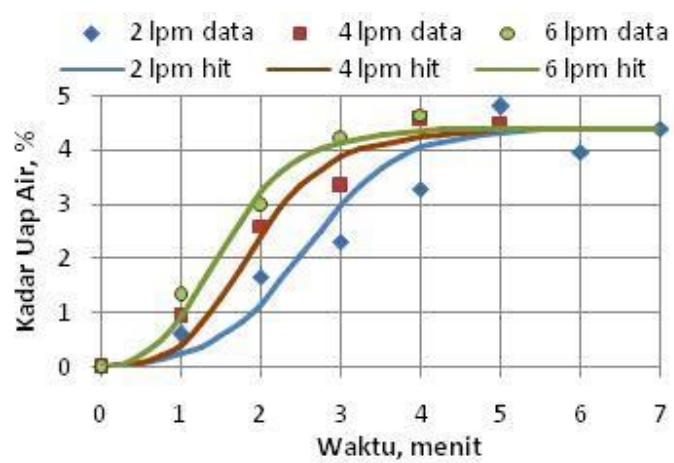

(c). $95^{\circ} \mathrm{C}$
Bahan baku yang dipakai adalah etanol $95,61 \%$ dan air 4,39\%. Secara teoritis semua data hasil percobaan akan memiliki kadar air kurang dari 4,39\%. Tetapi jika dilihat pada Tabel 2 terdapat beberapa data yang memiliki kadar air lebih besar dari 4,39\%. Hal ini ditandai dengan memberi warna abu-abu pada tabel data percobaan. Penyimpangan ini diduga karena adsorben telah jenuh dan jika terjadi gesekan / tumbukan dengan molekul lainnya maka molekul air yang menempel dengan lemah akan mudah terlepas lagi dan terikut keluar packed bed.

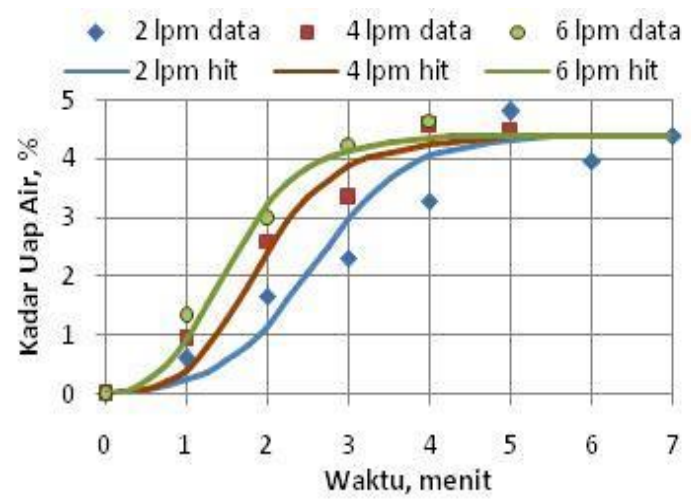

(b) $.90^{\circ} \mathrm{C}$

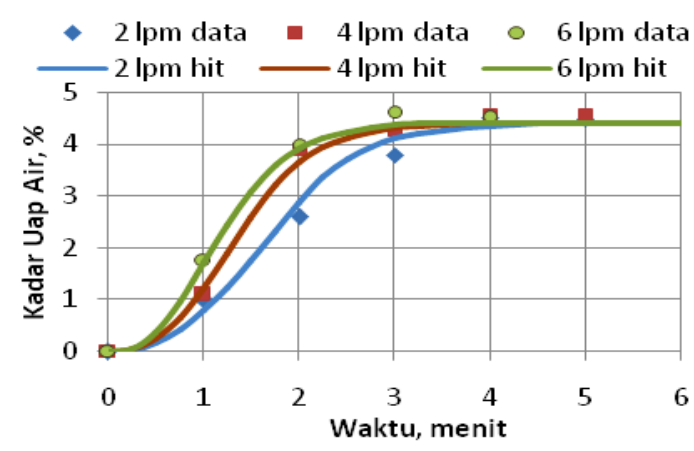

(d). $100^{\circ} \mathrm{C}$

Gambar 8. Hubungan kadar air terhadap waktu pada suhu (a) 85 , (b) 90 , (c) 95 , (d) $100^{\circ} \mathrm{C}$. 
Tabel 3. Nilai $H^{\prime}, k_{c}$, dan $D e_{r}$ pada berbagai laju alir dan suhu

\begin{tabular}{cccccccccc}
\hline \multirow{2}{*}{$T,{ }^{\circ} \mathrm{C}$} & \multicolumn{3}{c}{$2 \mathrm{lpm}$} & \multicolumn{9}{c}{$4 \mathrm{lpm}$} & \multicolumn{3}{c}{$6 \mathrm{lpm}$} \\
\cline { 2 - 9 } & $H^{\prime}$ & $k_{c}$ & $D e_{r}$ & $H^{\prime}$ & $k_{c}$ & $D e_{r}$ & $H^{\prime}$ & $k_{c}$ & $D e_{r}$ \\
\hline 80 & 6,44 & $2,03 \times 10^{-2}$ & $1,57 \times 10^{-3}$ & 6,36 & $2,34 \times 10^{-2}$ & $1,59.10^{-3}$ & 6,33 & $2,49 \times 10^{-2}$ & $1,60 \times 10^{-3}$ \\
85 & 5,72 & $2,05 \times 10^{-2}$ & $1,57 \times 10^{-3}$ & 5,69 & $2,34 \times 10^{-2}$ & $1,59.10^{-3}$ & 5,64 & $2,50 \times 10^{-2}$ & $1,61 \times 10^{-3}$ \\
90 & 5,35 & $2,06 \times 10^{-2}$ & $1,57 \times 10^{-3}$ & 5,32 & $2,36 \times 10^{-2}$ & $1,59.10^{-3}$ & 5,29 & $2,51 \times 10^{-2}$ & $1,61 \times 10^{-3}$ \\
95 & 4,91 & $2,07 \times 10^{-2}$ & $1,57 \times 10^{-3}$ & 4,88 & $2,36 \times 10^{-2}$ & $1,59.10^{-3}$ & 4,85 & $2,51 \times 10^{-2}$ & $1,61 \times 10^{-3}$ \\
100 & 4,26 & $2,08 \times 10^{-2}$ & $1,58 \times 10^{-3}$ & 4,23 & $2,37 \times 10^{-2}$ & $1,60.10^{-3}$ & 4,20 & $2,52 \times 10^{-2}$ & $1,61 \times 10^{-3}$ \\
\hline
\end{tabular}

Tabel 4. Nilai $H^{\prime}, k_{c}$, dan $D e_{r}$ terkoreksi

\begin{tabular}{cccccccccc}
\hline \multirow{2}{*}{$T,{ }^{\circ} \mathrm{C}$} & \multicolumn{9}{c}{$2 \mathrm{lpm}$} \\
\cline { 2 - 9 } & $H^{\prime}$ & $k_{c}$ & $D e_{r}$ & $H^{\prime}$ & $k_{c}$ & $D e_{r}$ & $H^{\prime}$ & $k_{c}$ & $D e_{r}$ \\
\hline 80 & 6,37 & $2,08 \times 10^{-2}$ & $1,59 \times 10^{-3}$ & 6,37 & $2,36 \times 10^{-2}$ & $1,59 \times 10^{-3}$ & 6,37 & $2,48 \times 10^{-2}$ & $1,59 \times 10^{-3}$ \\
85 & 5,68 & $2,08 \times 10^{-2}$ & $1,59 \times 10^{-3}$ & 5,68 & $2,36 \times 10^{-2}$ & $1,59 \times 10^{-3}$ & 5,68 & $2,48 \times 10^{-2}$ & $1,59 \times 10^{-3}$ \\
90 & 5,31 & $2,08 \times 10^{-2}$ & $1,59 \times 10^{-3}$ & 5,31 & $2,36 \times 10^{-2}$ & $1,59 \times 10^{-3}$ & 5,31 & $2,48 \times 10^{-2}$ & $1,59 \times 10^{-3}$ \\
95 & 4,88 & $2,08 \times 10^{-2}$ & $1,59 \times 10^{-3}$ & 4,88 & $2,36 \times 10^{-2}$ & $1,59 \times 10^{-3}$ & 4,88 & $2,48 \times 10^{-2}$ & $1,59 \times 10^{-3}$ \\
100 & 4,22 & $2,08 \times 10^{-2}$ & $1,59 \times 10^{-3}$ & 4,22 & $2,36 \times 10^{-2}$ & $1,59 \times 10^{-3}$ & 4,22 & $2,48 \times 10^{-2}$ & $1,59 \times 10^{-3}$ \\
\hline
\end{tabular}

Data pada suhu lainnya yaitu $85,90,95$ dan $100^{\circ} \mathrm{C}$ disajikan pada Gambar 8. Persentase air terendah selalu terjadi pada menit pertama, ini terjadi dikarenakan masih banyak area aktif pada permukaan adsorben sehingga banyak air yang terserap. Lalu pada menit selanjutnya kadar air meningkat sampai kondisi jenuhnya sampai di atas 4,39\% dan selanjutnya nilainya akan bersifat fluktuatif. Hal ini terjadi karena adsorben sudah pada kondisi jenuh atau kondisi telah setimbang.

\subsection{Kapasitas Adsorpsi Zeolit 4A}

Secara keseluruhan, suhu optimal percobaan ada pada $80^{\circ} \mathrm{C}$ dan laju alir optimal pada $2 \mathrm{lpm}$. Pada kondisi ini, kapasitas serap oleh zeolit 4A berada pada jumlah tertinggi uap air yang terserap oleh zeolit $4 \mathrm{~A}$ ada pada suhu $80^{\circ} \mathrm{C}$ dan laju alir 2 lpm yaitu 7,93 gram.

\subsection{Analisis Koefisien $H^{\prime}, k_{c}$ dan $D e_{r}$ Terhadap $v_{z}$ dan $T$}

Nilai parameter $H^{\prime}, k_{c}$, dan $D e_{r}$ yang diperoleh dari evaluasi dengan cara numerik ditampilkan pada Tabel 3. Berdasarkan Tabel 3 dapat disimpulkan bahwa faktor-faktor terbesar yang menentukan besarnya koefisien-koefisien di atas adalah sebagai berikut: $H^{\prime}=$ fungsi $(T), k_{c}=$ fungsi $\left(v_{z}\right)$ dan $D e_{r}=$ bukan fungsi $\left(T, v_{z}\right)$.
Sehingga perlu dicari $H^{\prime}, k_{c}$ dan $D e_{r}$ terkoreksi dengan cara sebagai berikut: mula-mula nilai $D e_{r}$ untuk semua data dirata-rata, dan input data dikeluarkan dari tebakan program. Lalu didapat $H^{\prime}$ dan $k c$ yang baru. Lalu nilai $k_{c}$ baru dirata-rata tiap laju alir dan dikeluarkan dari tebakan program. Maka didapat nilai $H^{\prime}$ baru lagi, dan nilai $H^{\prime}$ dirata-rata tiap masing-masing suhu. Tabel 4 menunjukkan nilai $H^{\prime}, k_{c}$ dan $D e_{r}$ terkoreksi.

Hubungan antara $k_{c}$ dengan variabel-variabel yang mempengaruhi dinyatakan dalam persamaan Sherwood (Persamaan 8) (Mardina, 2007)

$$
S h=A \cdot R e^{B} \cdot S c^{C}
$$

dengan:

$$
\begin{array}{ll}
\operatorname{Re} & =\text { bilangan Reynolds } \\
S c & =\text { bilangan Schmidt } \\
A, B, C & =\text { konstanta }
\end{array}
$$

Pada percobaan ini proses berjalan isotermal dan bahan tidak diubah maka bilangan Schmidt (Sc) tetap, sehingga persamaan menjadi (Persamaan 9):

$$
k_{c}=A^{\prime} \cdot\left(\frac{\rho \cdot v_{z} \cdot D}{\mu}\right)^{B}
$$

Linierisasi Persamaan 9 di atas dan setelah dilakukan regresi linier, maka didapat hasil sebagai berikut: 


$$
k_{c}=7,95 \times 10^{-3} \cdot\left(\frac{\rho v_{Z} D}{\mu}\right)^{0,1639}
$$

Hubungan $H^{\prime}=$ fungsi $(T)$ didekati dengan menggunakan persamaan mirip persamaan Arrhenius, sehingga didapatkan Persamaan 11.

$$
H^{\prime}=4,47 \times 10^{-3} \exp (2565,26 / T)
$$

\section{Kesimpulan}

Berdasarkan hasil penelitian dan tujuan-tujuan penelitian yang ingin diketahui dan dipelajari, maka dapat disimpulkan bahwa:

1. Proses adsorpsi air dari campuran etanol-air dengan mengunakan zeolit $4 \mathrm{~A}$ bisa dilakukan dan memberikan hasil tertinggi berupa etanol dengan kadar 99,40\%.

2. Laju alir uap 2 liter per menit dan suhu $80^{\circ} \mathrm{C}$ adalah kombinasi yang optimal dalam penelitian ini. Pada kondisi ini banyak uap air yang teradsorp pada butir zeolit $4 \mathrm{~A}$ yaitu 7,93 gram.

3. Nilai $D e_{\mathrm{r}}$ pada percobaan ini adalah $1,59 \times 10^{-3}$ $\mathrm{cm}^{2} /$ men, serta hubungan $k_{c}$ fungsi Reynold dan $H^{\prime}$ ' fungsi suhu berturut-turut adalah sebagai berikut

$$
\begin{aligned}
& k_{c}=7,95 \times 10^{-3} \cdot\left(\frac{\rho \cdot v_{z} \cdot D}{\mu}\right)^{0,164} \mathrm{dan} \\
& H^{\prime}=4,47 \times 10^{-3} \cdot e^{\left(\frac{2565,26}{T}\right)}
\end{aligned}
$$

\section{Daftar Notasi}

$a=$ luas permukaan partikel adsorben per unit volume tumpukan bed $\left(\mathrm{cm}^{2} / \mathrm{cm}^{3}\right)$

$C_{A}=$ konsentrasi adsorbate dalam uap di sela - sela partikel setiap saat $\left(\mathrm{g} / \mathrm{cm}^{3}\right)$

$C_{A}{ }^{*}=$ konsentrasi adsorbate dalam uap yang setimbang dengan konsentrasi adsorbate pada permukaan butir adsorben $\left(\mathrm{g} / \mathrm{cm}^{3}\right)$

$D=$ diameter bed $(\mathrm{cm})$

$D e_{r}=$ difusivitas efektif radial $\left(\mathrm{cm}^{2} /\right.$ menit $)$

$H=$ konstanta Henry

$k_{c}=$ koefisien transfer massa adsorbate dari uap ke permukaan butir adsorben (cm/menit)

$P_{t} \quad=$ tekanan total (atm)

$Q=$ debit fluida $\left(\mathrm{cm}^{3} /\right.$ menit $)$

$r \quad=$ jari-jari adsorben $(\mathrm{cm})$

$S \quad=$ luas penampang kolom $(\mathrm{cm})$ $t=$ waktu (menit)

$T=\operatorname{suhu}\left({ }^{\circ} \mathrm{C}\right)$

$v_{z} \quad=$ laju alir fluida $(\mathrm{cm} / \mathrm{menit})$

$X_{A}=$ fraksi massa adsorbate teradsorpsi

$y_{A}=$ fraksi massa adsorbate pada fase gas

$z \quad=$ tinggi bed $(\mathrm{cm})$

$H^{\prime} \quad=$ konstanta Henry per tekanan total

$\varepsilon_{b} \quad=$ porositas bed

$\varepsilon_{p} \quad=$ porositas partikel

$\rho \quad=$ densitas bulk adsorben $\left(\mathrm{g} / \mathrm{cm}^{3}\right)$

$\rho_{s} \quad=$ densitas adsorben $\left(\mathrm{g} / \mathrm{cm}^{3}\right)$

$\mu \quad=\operatorname{viskositas}(\mathrm{g} /(\mathrm{cm} \cdot m e n i t))$

\section{Daftar Pustaka}

Abu-Lail L., Bergendahl, J. A., and Thompson, R.W., 2014, Mathematical modelling of chloroform adsorption onto fixed-bed columns of highly siliceous granular zeolites, Enviromental Progress \& Sustainable Energy, 31 (4), 591-596.

Castellan, G.W., 1982, Physical Chemistry, 3rd Ed, p. 427, Addison-Weasley Publising Company, Inc, New York.

Cheknane, B., Baudu, M., Bouras, O., and Zermane, F., 2016, Modelling of basic green for dynamic sorption onto granular organoinorgano pillared clays (GOICs) in column reactor, Chem. Eng. J., 209, 7-12.

Díaz, J.C., Gil-Chávez, I.D., Giraldo, L., and Moreno-Piraján, J. C., 2010, Separation of ethanol-water mixture using type-A zeolite molecular sieve, E. J. Chem., 7, 483-495.

Flanigen, E.M., 1991, Zeolite and Molecular Sieves an Historical Perspective, New York : Elsevier Science.

Foo, K.Y. and Hameed, B. H., 2010, Review insight into the modelling of adsorpstion isoterm system, Chem. Eng. J, 156, 2-0.

Ivanova, E., Damgaliev, D., and Kostova, M., 2009, Adsorption separation of ethanol-water liquid mixtures by natural clinoptilolite, J. Univ. Chem. Technol. Met., 44, 267-274.

Khaidir, 2011, Modifikasi Zeolit Alam Sebagai Material Molecular Sieve dan Aplikasinya Pada Proses Dehidrasi Bioetanol: Sekolah Pascasarjana Institut Pertanian Bogor. Bogor. 
Kohl, S., 2004, Ethanol Dehidration: Ethanol Today, Edition March 2004. http://www.ovsclub.com

Mardina, P., 2007, Menentukan koefisien transfer massa dan diffusvitas efektif dari proses dekolorisasi zat warna, Info Teknik, Volume 8, 29-41.

Mortimer, M. and Taylor P., 2002, Chemical Kinetics and Mechanism, RSC, Cambridge

Novitasari, D., Kusumaningrum, D., dan Kusworo, T.D., 2012, Pemurnian bioetanol menggunakan proses adsorbsi dan distilasi adsorbsi dengan adsorbent zeolit, jurnal teknologi kimia dan industri, Vol. 1, No. 1., 534-539.

Perry, R.H., and Green, D.W., 1997, Perry's Chemical Engineers' Handbook, 7th Edition, Mc Graw-Hill Co, New York, p.1128, 14901497, 1534-1537.

Rutz, D. and Janssen, R., 2008, Biofuel Technology Handbook, WIP Renewable Energy, Munchen, p.55.

Sediawan, W. B. dan Prasetya, A., 1997, Pemodelan Matematis dan Penyelesaian Numeris dalam Teknik Kimia dengan Bahasa Basic dan Fortran, Ed. 1, ANDI, Yogyakarta.
Setyadji, M., Masduki, B., Herhady, D., dan Wasito, B., 1996, Simulasi Perhitungan Koefisien Perpindahan Massa dan Diffusivitas Efektif Aksial Uranium pada Pemisahan Uranium dari Hasil Belah dengan Cara Pertukaran Ion, Pusat Penelitian Nuklir, Yogyakarta.

Silvia, M. dan Darmawan, R., 2012, Pengambilan Air dari Sistem Isopropil Alkohol-Air dengan Distilasi Adsortif Menggunakan Zeolit Alam dan Silika Gel, Universitas Diponegoro, Semarang.

Sutarti, M. dan Rachmawati, 1994, Zeolit Tinjauan Literatur, Pusat Dokumentasi dan Informasi Ilmiah, LIPI, Jakarta.

Treyball, R.E., 1981, Mass Transfer Operation, 3rd Edition. John Wiley and Sons, Inc. New Jersey. p.11,157,158,186,187. 